\title{
PENGARUH RISIKO TERHADAP PROFITABILITAS DI PERUSAHAAN MINUMAN BERALKOHOL YANG TERCATAT DI BURSA EFEK INDONESIA
}

\author{
Tiara Andani Suzuki ${ }^{1}$, Veny Anindya Puspitasari ${ }^{2}$ \\ Fakultas Ekonomi, Bisnis dan Ilmu Sosial, Universitas Matana ${ }^{1}$ \\ Fakultas Ekonomi, Universitas Multimedia Nusantara ${ }^{2}$ \\ E-mail: tiara.andani17@gmail.com
}

\begin{abstract}
This study aims to determine the influence of systematic risk and unsystematic risk on profitability in alcoholic beverage companies in Indonesia Stock Exchange during period 2013-2017. The methodology used in this study is a quantitative and descriptive approach. The population and sample in this study are the same, because alcoholic beverage companies listed on the IDX only have 2 companies. The type of data used is secondary data originating from the official website. Data analysis techniques using Multiple Linear Regression Analysis and Pool Data Regression Analysis are assisted by the application of Eviews 10 to find out the classic assumption test and hypothesis test (partial and simultaneous). The results of this study indicate that interest rate risk, inflation risk, likuidity risk, credit risk, and Operational risk have an unsignificant negative effect on profitability, however exchange rate risk has a significant negative effect on profitability. Originality in this research has no much research that use alcoholic beverages componies which produce alcoholic beverages type A during government released the rule about doesn't allow to sell alcoholic beverages in convenience store.
\end{abstract}

Keywords : Systematic Risk, Unsystematic Rick, Profitability and Pool Data.

\section{Pendahuluan}

Industri makanan dan minuman merupakan sektor andalan penopang pertumbuhan manufaktur dan ekonomi Indonesia. Hal ini dapat dilihat dari besarnya kontribusi industri makanan dan minuman terhadap Produk Domestik Bruto (PDB) di Indonesia (Prahara, 2018). Pertumbuhan industri makanan dan minuman mengalami peningkatan pada tahun 2016 sebesar 8, 46\% menjadi 9, 23\% di tahun 2017 (Yasmin, 2018). Akan tetapi, industri makanan dan minuman, khususnya industri minuman tidak selalu dalam keadaan baik.

Banyaknya peraturan yang dikeluarkan oleh pemerintahan Republik Indonesia pada tahun 2015, menjadi penyebab utama yang membuat industri makanan dan minuman, khususnya industri minuman beralkohol menjadi kewalahan untuk menanggulangi kerugian yang disebabkan karena munculnya peraturan yang merugikan bagi pihak industri minuman beralkohol. Salah satu peraturan tersebut adalah Peraturan Menteri Perdagangan Republik Indonesia Nomor 06/M-Dag/PER/1/2015 pasal 2 ayat 2 tentang Perubahan Kedua Atas Peraturan Menteri Perdagangan Nomor 20/M-Dag/PER/4/2014 tentang Pengendalian dan Pengawasan Terhadap Pengadaan, Peredaran, dan Penjualan Minuman Beralkohol yang berbunyi "Pengecer Minuman Beralkohol skala minimarket dan pengecer lainnya, paling lambat 3 (tiga) bulan harus sudah menarik produk Minuman Beralkohol golongan A dari peredaran." Peraturan Menteri ini berlaku pada tanggal 16 Januari 2015. Menurut Peraturan Menteri Perdagangan Nomor 20/M-Dag/PER/4/2014 pasal 2 tentang Pengendalian dan Pengawasan Terhadap Pengadaan, Peredaran, dan Penjualan Minuman Beralkohol, "Minuman Beralkohol golongan A adalah minuman yang mengandung etil alcohol atau etanol $\left(\mathrm{C}_{2} \mathrm{H}_{5} \mathrm{OH}\right)$ dengan kadar sampai dengan 5\% (lima per seratus)". 
Akan tetapi, minuman beralkohol telah menjadi gaya hidup masyarakat Indonesia sejak zaman penjajahan bangsa Eropa. Di Indonesia, tepatnya di daerah Jawa, sejak tahun 1931 telah dibangun pabrik minuman beralkohol untuk memenuhi kebutuhan para penjajah. Pabrik ini juga telah memberikan banyak bantuan bagi perekonomian kota (Anwari, 2015). Hingga saat ini, perusahaan industri minuman beralkohol di Indonesia telah berperan dalam menambah kas negara dari nilai cukai senilai Rp5,27 triliun pada 2017, naik sekitar 2,63\% dibandingkan dengan penerimaan cukai tahun 2016 yang mencapai Rp5,14 triliun dan dalam 5 tahun terakhir, rata-rata pertumbuhan nilai ekspor bir tercatat hingga $12 \%$ per tahun (Rini, 2018).

Di Indonesia sendiri terdapat perusahaan minuman beralkohol yang tercatat di Bursa Efek Indonesia hingga saat ini. Perusahaan tersebut adalah PT Multi Bintang Indonesia Tbk (MLBI) dan PT Delta Djakarta Tbk (DLTA). Kedua perusahaan tersebut terkena dampak akan peraturan-peraturan yang dikeluarkan pada tahun 2015, merupakan tahun yang sulit bagi perseroan dan industri bir. Hal ini dapat dibuktikan dengan adanya penurunan penjualan bersih pada industri minuman beralkohol, contohnya: MLBI mengalami penurunan, khususnya penjualan bersih sebanyak kurang lebih $10 \%$ dari penjualan bersih di tahun 2014, sedangkan DLTA mengalami penurunan, khususnya penjualan bersih dari tahun 2014 sebanyak Rp879.252.000.000,- menjadi sebanyak Rp699.507.000.000,- pada tahun 2016. Untuk itu, penulis ingin mengetahui bagaimana risiko yang ada mempengaruhi profitabilitas perusahaan-perusahaan tersebut.

Adapun masalah yang dihadapi penulis dalam penelitian ini adalah sebagai berikut:

1. Bagaimana pengaruh risiko tingkat suku bunga terhadap profitabilitas di perusahaan minuman beralkohol yang tercatat di BEI periode 2013-2017?

2. Bagaimana pengaruh risiko inflasi terhadap profitabilitas di perusahaan minuman beralkohol yang tercatat di BEI periode 2013-2017?

3. Bagaimana pengaruh risiko nilai tukar valuta asing terhadap profitabilitas di perusahaan minuman beralkohol yang tercatat di BEI periode 2013-2017?

4. Bagaimana pengaruh risiko likuiditas terhadap profitabilitas di perusahaan minuman beralkohol yang tercatat di BEI periode 2013-2017?

5. Bagaimana pengaruh risiko kredit terhadap profitabilitas di perusahaan minuman beralkohol yang tercatat di BEI periode 2013-2017?

6. Bagaimana pengaruh risiko operasional terhadap profitabilitas di perusahaan minuman beralkohol yang tercatat di BEI periode 2013-2017?

7. Bagaimana pengaruh risiko sistematis dan risiko tidak sistematis terhadap profitabilitas di perusahaan minuman beralkohol yang tercatat di BEI periode 2013-2017?

\section{Tinjauan Literatur dan Pengembangan Hipotesis}

Wibowo dan Syaichu (2013) dalam artikelnya yang bertajuk "Analisis Pengaruh Suku Bunga, Inflasi, CAR, BOPO, NPF Terhadap Profitabilitas Bank Syariah" mendapati bahwa inflasi memiliki arah negatif namun tidak memiliki pengaruh yang signifikan terhadap ROA; sedangkan suku bunga, CAR, dan NPF tidak memiliki pengaruh yang signifikan terhadap ROA; sementara BOPO berpengaruh signifikan negatif terhadap ROA.

Mansyur (2018) dalam artikelnya berjudul "Pengaruh Risiko Pasar Terhadap Profitabilitas Perusahaan Sub Sektor Bank pada Bursa Efek Indonesia" mendapati hasil bahwa risiko suku bunga berpengaruh positif dan signifikan terhadap profitabilitas sedangkan risiko nilai tukar valuta asing berpengaruh negatif dan signifikan terhadap profitabilitas.

Rahmi (2014) mendapati bahwa risiko tingkat bunga berpengaruh signifikan positif terhadap profitabilitas, risiko kredit berpengaruh signifikan negatif terhadap profotabilitas, dan risiko likuiditas tidak berpengaruh signifikan terhadap profitabilitas seperti yang tertuang 
dalam artikelnya yang berjudul "Pengaruh Risiko Kredit, Risiko Likuiditas, dan Risiko Tingkat Bunga Terhadap Profitabilitas (Studi empiris pada perusahaan perbankan yang terdaftar di Bursa Efek Indonesia)".

Sementara itu dalam artikel yang bertajuk "Pengaruh Risiko Kredit dan Tingkat Kecukupan Modal Terhadap Tingkat Profitabilitas pada Perusahaan Perbankan yang Terdaftar di Bursa Efek Indonesia" yang ditulis oleh Putri (2013) didapati bahwa risiko kredit mempunyai pengaruh negatif dan signifikan terhadap profitabilitas, sedangkan tingkat kecukupan modal (CAR) berpengaruh positif dan signifikan terhadap profitabilitas.

Tommy, Christiano, \& Saerang (2014) menyatakan bahwa NPL tidak berpengaruh signifikan terhadap ROA; sedangkan BOPO berpengaruh negatif terhadap ROA; sementara LDR, CAR, dan NIM berpengaruh positif terhadap ROA yang tertuang dalam artikelnya yang berjudul "Analisis Terhadap Rasio-Rasio Keuangan untuk mengukur Profitabilitas pada BankBank Swasta yang Go Publik di Bursa Efek Indonesia".

Serupa dengan penelitian yang dilakukan oleh Eng (2013) yang artikelnya berjudul "Pengaruh NIM, BOPO, LDR, NPL \& CAR Terhadap ROA Bank Internasional dan Bank Nasional Go Public Periode 2007-2011" yang mendapati hasil bahwa BOPO dan CAR tidak berpengaruh terhadap ROA; sedangkan LDR dan NPL memiliki pengaruh yang negatif dan signifikan terhadap ROA; serta NIM secara parsial berpengaruh signifikan terhadap ROA.

Sementara itu Yanti (2015) dalam artikelnya yang berjudul "Pengaruh Konservatisme Akuntansi, Risiko Sistematis, dan Ketepatwaktuan Informasi Terhadap Keresponan Laba pada Perusahaan Manufaktur yang Terdaftar di BEI Tahun 2009-2013" mendapati hasil bahwa konservatisme akuntansi memiliki pengaruh yang signifikan terhadap keresponan laba; sedangkan risiko sistematis dan ketepatwaktuan tidak berpengaruh terhadap keresponan laba.

Yudowati, Khairunnisa, \& Jati (2017) menyatakan dalam artikelnya yang berjudul "Pengaruh Risiko Sistematik, Persistensi Laba, dan Ukuran Perusahaan Terhadap Koefisien Respon Laba (Studi pada Perusahaan yang Terdaftar di Indeks Kompas100 Periode 20112015)" bahwa risiko sistematik dan ukuran perusahaan berpengaruh signifikan terhadap koefisien respon laba, sedangkan persistensi laba tidak berpengaruh terhadap koefisien respon laba. berikut:

Dari tinjauan literatur tersebut, maka penelitian ini memiliki kerangka sebagai

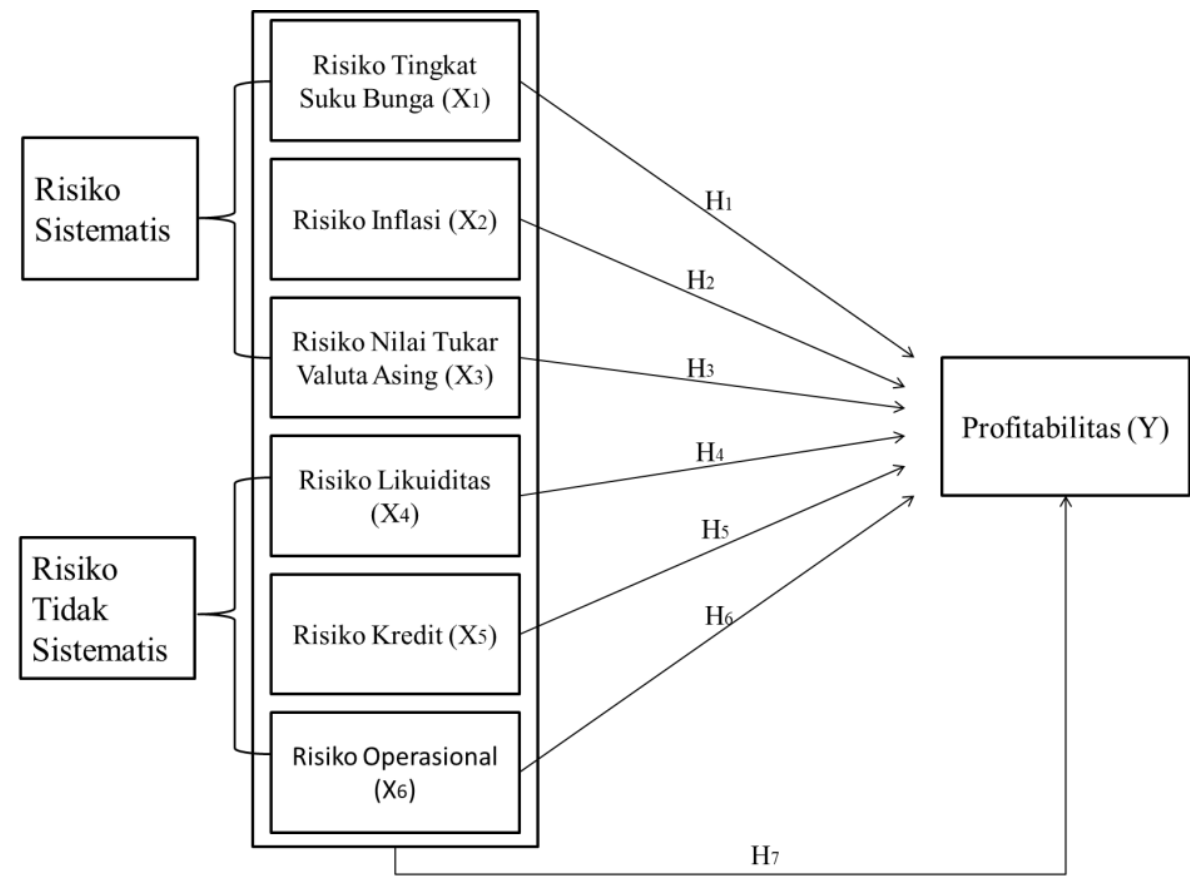


Adapun hipotesis yang terdapat dalam penelitian ini adalah sebagai berikut:

H1 : risiko tingkat suku bunga secara parsial berpengaruh positif signifikan terhadap profitabilitas di perusahaan minuman beralkohol yang tercatat di BEI periode 2013-2017

$\mathrm{H} 2$ : risiko inflasi secara parsial berpengaruh negatif signifikan terhadap profitabilitas di perusahaan minuman beralkohol yang tercatat di BEI periode 2013-2017

H3 : risiko nilai tukar valuta asing secara parsial berpengaruh negatif signifikan terhadap profitabilitas di perusahaan minuman beralkohol yang tercatat di BEI periode 2013-2017

H4 : risiko likuiditas secara parsial berpengaruh negatif signifikan terhadap profitabilitas di perusahaan minuman beralkohol yang tercatat di BEI periode 2013-2017

H5 : risiko kredit secara parsial berpengaruh negatif signifikan terhadap profitabilitas di perusahaan minuman beralkohol yang tercatat di BEI periode 2013-2017

H6 : risiko operasional secara parsial berpengaruh negatif signifikan terhadap profitabilitas di perusahaan minuman beralkohol yang tercatat di BEI periode 2013-2017.

H7 : risiko sistematis dan risiko tidak sistematis secara simultan tidak berpengaruh terhadap profitabilitas di perusahaan minuman beralkohol yang tercatat di BEI periode 2013-2017.

\section{Metode Penelitian}

Uji Simultan (Uji F). Uji statistik F dilakukan untuk menguji kemampuan seluruh variabel independen secara bersama-sama dalam menjelaskan perilaku variabel dependen. Pengujian dilakukan dengan menggunakan tingkat signifikansi 0,05 $(\alpha=5 \%)$.

Uji Parsial (Uji t). Uji t dilakukan untuk mengetahui kemampuan masing-masing variabel independen dalam menjelaskan perilaku variabel dependen. Pengujian dilakukan dengan menggunakan tingkat signifikansi $0,05(\alpha=5 \%)$.

Analisis Regresi Linier Berganda. Regresi linier berganda merupakan regresi yang menyediakan lebih dari satu variabel independen (X) dan satu variabel dependen (Y) (Kurniawan \& Yuniarto, 2016).

Teknik Estimasi Model Regresi Data Panel. Terdapat 3 teknik mengestimasi model regresi dalam data panel adalah sebagai berikut (Ansofino, Jolianis, Yolamalinda, \& Arfilindo, 2016, pp. 142-150):

a. Koefisien tetap antar waktu dan induvidu (Common Effect)

Teknik paling sederhana untuk mengestimasi data panel adalah hanya dengan mengkombinasikan data time series dengan cross section.

b. Slop konstan tetapi intersep berbeda antar individu (Fixed Effect)

Model ini mengestimasi data panel dengan menggunkan variabel dummy untuk menangkap adanya perbedaan intersep dan sering disebut dengan teknik Least Squares Dummy Variable (LSDV).

c. Random effect

Di dalam model ini kita akan mengestimasi data panel dimana variabel gangguan mengkin saling berhubungan antar waktu dan antar individu.

Analisis Regresi Data Panel. Terdapat 2 analisis regresi data panel adalah sebagai berikut (Ansofino, Jolianis, Yolamalinda, \& Arfilindo, 2016, pp. 153-154): 
a. Uji Signifikan Fixed Effect

Uji $F$ statistik dalam penelitian ini merupakan uji perbedaan dua regresi. Uji $F$ jika digunakan untuk mengetahui apakah teknik regresi data panel dengan fixed effect lebih baik dari model regresi data panel tanpa variabel dummy dengan residual sum of Squares (RSS). Adapun uji F statistiknya adalah sebagai berikut:

$$
F=\frac{\left(R S S_{1}-R S S_{2}\right) / m}{\left(R S S_{2}\right) /(n-k)}
$$

Dimana, $\mathrm{RSS}_{1}$ dan $\mathrm{RSS}_{2}$ merupakan residual sum of squares teknik tanpa variabel dummy dan teknik fixed effect dengan variabel dummy dan merupakan jumlah restriksi atau pembatasan di dalam model tanpa variabel dummy. Hipotesis nol adalah bahwa intersep adalah sama. Nilai statistik F hitung akan mengikuti distributor kebebasan (df) sebanyak $\mathrm{m}$ (numerator) dan sebanyak n-k (denumerator). $\mathrm{H}_{0}$ ditolak jika nilai dari probabilitas $\mathrm{F}$ lebih kecil dari alpha, yaitu lebih kecil dari 0.05, dimana $\mathrm{H}_{0}$ merupakan model pooled least square dan $\mathrm{H}_{1}$ adalah model fixed effect.

b. Uji Signifitan Random Effect

Untuk mengetahui model yang lebih baik antara fixed effect dengan random effect digunakan Hausman Test. Kemudian akan dilanjutkan dengan Uji Lagrangian Multiplier untuk menentukan apakah kita tetap memilih Random effect ataukah Common effect. Uji LM ini didasarkan pada distribusi chi-squares dengan degree of freedom sebesar variabel independen.

\section{Hasil Penelitian dan Pembahasan}

\section{Analisis Hasil Penelitian \\ Uji Normalitas}

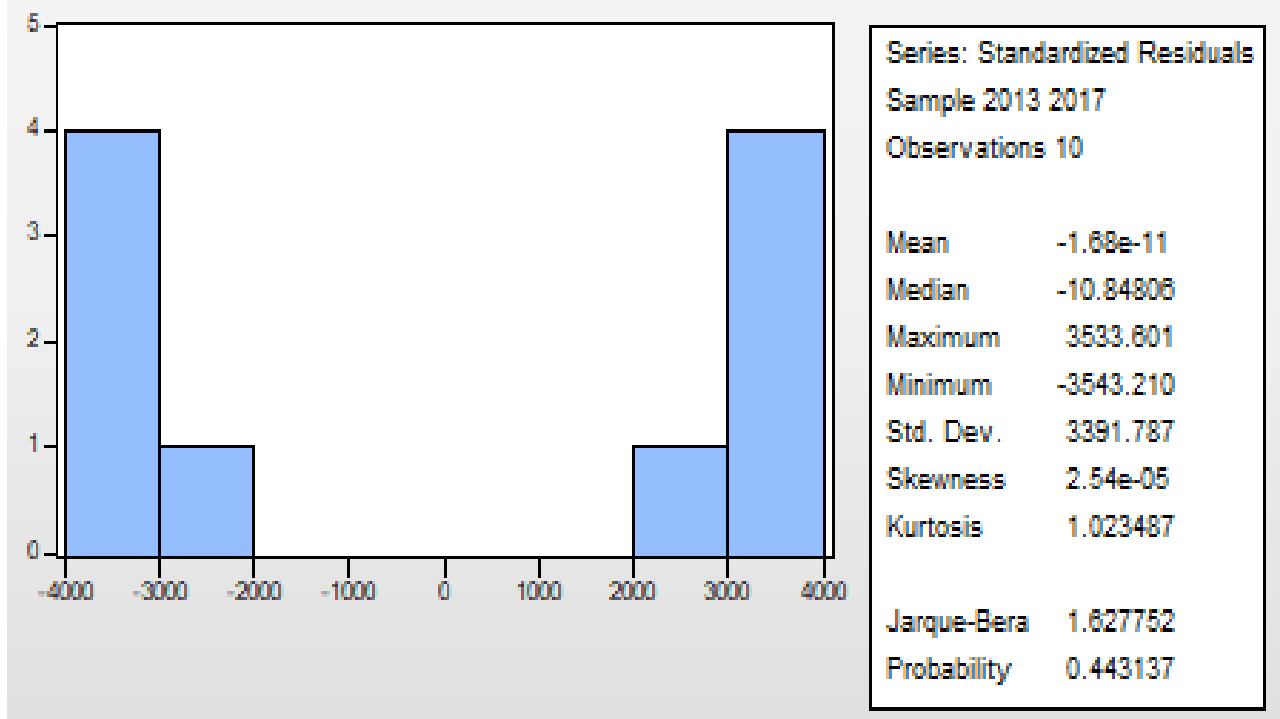

Gambar 1

Hasil Uji Normalitas

Berdasarkan gambar diatas dan berdasarkan kriteria yang telah disebutkan sebelumnya, penelitian ini memiliki nilai Jarque-Bare sebesar 1,627752, sedangkan nilai Probabilitas sebesar 0,443137. Dimana Jarque-Bera dan Probabilitas memenuhi kriteria Uji Jarque-Bera, sehingga dapat dinyatakan bahwa penelitian yang dilakukan telah memenuhi uji normalitas dengan hasil data berdistribusi normal. 


\section{Uji Parsiat (t)}

Tabel 1

Kesimpulan Uji T

\begin{tabular}{|c|c|c|c|c|c|}
\hline \multirow{2}{*}{$\begin{array}{l}\text { Variabel } \\
\text { Independen }\end{array}$} & \multicolumn{2}{|c|}{$\begin{array}{l}\text { Pengaruh Variabel Independen } \\
\text { terhadap Variabel Dependen }\end{array}$} & \multirow{2}{*}{$\begin{array}{c}\text { Nilai } \\
\text { probabilitas }\end{array}$} & \multirow[t]{2}{*}{ Signifikansi } & \multirow[t]{2}{*}{ Kesimpulan } \\
\hline & Hipotesis & Hasil Uji T & & & \\
\hline $\begin{array}{l}\text { Risiko Tingkat } \\
\text { Suku Bunga }\end{array}$ & $\begin{array}{l}\mathrm{H}_{1} \text { : positif } \\
\text { signifikan }\end{array}$ & Positif & 0,1799 & $\begin{array}{c}\text { Tidak } \\
\text { signifikan }\end{array}$ & $\mathrm{H}_{1}$ ditolak \\
\hline Risiko Inflasi & $\begin{array}{c}\mathrm{H}_{2} \text { : negatif } \\
\text { signifikan }\end{array}$ & Negatif & 0,1169 & $\begin{array}{c}\text { Tidak } \\
\text { signifikan }\end{array}$ & $\mathrm{H}_{2}$ ditolak \\
\hline $\begin{array}{c}\text { Risiko Nilai } \\
\text { Tukar Valuta } \\
\text { Asing }\end{array}$ & $\begin{array}{l}\mathrm{H}_{3} \text { : negatif } \\
\text { signifikan }\end{array}$ & Negatif & 0,0356 & Signifikan & $\mathrm{H}_{3}$ diterima \\
\hline $\begin{array}{l}\text { Risiko } \\
\text { Likuiditas }\end{array}$ & $\begin{array}{l}\mathrm{H}_{4}: \text { negatif } \\
\text { signifikan }\end{array}$ & Negatif & 0,7022 & $\begin{array}{c}\text { Tidak } \\
\text { signifikan }\end{array}$ & $\mathrm{H}_{4}$ ditolak \\
\hline Risiko Kredit & $\begin{array}{l}\mathrm{H}_{5}: \text { negatif } \\
\text { signifikan }\end{array}$ & Negatif & 0,0808 & $\begin{array}{l}\text { Tidak } \\
\text { signifikan }\end{array}$ & $\mathrm{H}_{5}$ ditolak \\
\hline $\begin{array}{c}\text { Risiko } \\
\text { Operasional } \\
\end{array}$ & $\begin{array}{l}\mathrm{H}_{6}: \text { negatif } \\
\text { signifikan }\end{array}$ & Negatif & 0,2694 & $\begin{array}{c}\text { Tidak } \\
\text { signifikan } \\
\end{array}$ & $\mathrm{H}_{6}$ ditolak \\
\hline
\end{tabular}

\section{Uji Simultan (Uji F)}

Tabel 2

Hasil Uji F dan Uji Koefisien Determinasi dengan Regresi Linier Berganda

\begin{tabular}{llll}
\hline \hline R-squared & 0.924264 & Mean dependentvar & 157.4355 \\
Adjusted R-squared & 0.772791 & S.D. dependentvar & 1130.716 \\
S.E. of regression & 538.9723 & Sum squared resid & 871473.3 \\
F-statistic & 6.101851 & Durbin-Watson stat & 2.393558 \\
Prob(F-statistic) & 0.083124 & & \\
\hline
\end{tabular}

Dalam penelitian ini uji $F$-statistic, diperoleh nilai sebesar 6,101851, sedangkan nilai probabilitasnya adalah sebesar 0,083124 yang menunjukkan nilai probabilitas lebih besar daripada nilai standarnya, yaitu 5\%, maka dapat disimpulkan bahwa penelitian ini menerima hipotesis $\mathrm{H}_{7}$, yang berarti risiko sistematis dan risiko tidak sistematis tidak memiliki pengaruh terhadap variabel dependen, yaitu profitabilitas.

\section{Uji Koefisien Determinasi $\left(\mathbf{R}^{\mathbf{2}}\right)$}

Berdasarkan tabel sebelumnya, koefisien determinasi dalam penelitian ini dilabelkan dengan adjusted $R$-squared. Nilai adjusted $R$-squared dalam penelitian ini adalah sebesar 0,772791 atau $77,2791 \%$. Sehingga, dalam penelitian ini memiliki proporsi pengaruh yang sangat kuat terhadap variabel Y, yaitu sebesar $77,2791 \%$, sedangkan sisanya sebesar $22,7209 \%(100 \%-77,2791 \%)$ yang dipengaruhi oleh variabel lain yang tidak terdapat di dalam model regresi penelitian ini. 


\section{Pembahasan}

\section{Pengaruh Risiko Tingkat Suku Bunga terhadap Profitabilitas}

Berdasarkan hasil pengujian hipotesis pertama $\left(\mathrm{H}_{1}\right)$ ditunjukkan bahwa secara parsial risiko tingkat suku bunga berpengaruh positif tetapi tidak signifikan terhadap profitabilitas. $\mathrm{Hal}$ ini dapat dilihat dari nilai probabilitas risiko tingkat suku bunga $\left(\mathrm{X}_{1}\right)$ lebih besar daripada nilai kritis atau nilai standar 5\%, yaitu sebesar 0,1799 dengan nilai coefficient positif, yaitu sebesar 0,588478. Hasil penelitian ini dapat dijelaskan dari kedua perusahaan minuman beralkohol yang digunakan sebagai sampel dalam penelitian ini memiliki hutang usaha yang tergolong sedikit atau bahkan tidak memiliki hutang usaha terhadap bank dalam periode 2013-2017 (dimana suku bunga kredit menggunakan BI Rate), melainkan kedua perusahaan memiliki produk investasi yang dapat diakui sebagai penghasilan tambahan, sehingga pengaruh dari variabel $\mathrm{X}_{1}$ dianggap tidak terlalu berpengaruh terhadap profitabilitas di dalam perusahaan. Hasil penelitian ini sejalan dengan penelitian yang dilakukan oleh Syaichu dan Wibowo (2013), akan tetapi berbeda dengan hasil penelitian yang dilakukan oleh Mansyur (2018) dan Rahmi (2014).

\section{Pengaruh Risiko Nilai Tukar Valuta Asing terhadap Profitabilitas}

Berdasarkan hasil pengujian hipotesis ketiga $\left(\mathrm{H}_{3}\right)$ ditunjukkan bahwa secara parsial risiko nilai tukar valuta asing berpengaruh negatif signifikan terhadap profitabilitas. Hal ini dapat dilihat dari nilai probabilitas risiko nilai tukar valuta asing $\left(\mathrm{X}_{3}\right)$ lebih kecil daripada nilai kritis atau nilai standar 5\%, yaitu sebesar 0,0356 dengan nilai coefficient negatif, yaitu sebesar -1,035924. Penerapan tarif bea masuk impor pada tahun 2012 menjadi salah satu faktor utama menurunnya profitabitas di kedua perusahaan minuman beralkohol ini, pasalnya kedua perusahaan minuman beralkohol ini masih mengimpor bahan dasar pembuatan minuman beralkohol dari Negara lain (Sumber: Annual Report DLTA), sehingga perubahan nilai valuta asing sangat berpengaruh terhadap profitabilitas di perusahaan minuman beralkohol. Hasil penelitian ini tidak sejalan dengan penelitian yang dilakukan oleh Mansyur (2018) yang menyatakan bahwa risiko nilai tukar valuta asing berpengaruh negatif dan signifikan terhadap profitabilitas.

\section{Pengaruh Risiko Likuiditas terhadap Profitabilitas}

Berdasarkan hasil pengujian hipotesis keempat $\left(\mathrm{H}_{4}\right)$ ditunjukkan bahwa secara parsial risiko likuiditas berpengaruh negatif, tetapi tidak signifikan terhadap profitabilitas. Hal ini dapat dilihat dari nilai probabilitas risiko likuiditas $\left(\mathrm{X}_{4}\right)$ lebih besar daripada nilai kritis atau nilai standar 5\%, yaitu sebesar 0,7022 dengan nilai coefficient negatif, yaitu sebesar 0,010400. Risiko likuiditas dalam penelitian ini dihitung menggunakan current ratio, sehingga jika current ratio tinggi maka kemampuan perusahaan untuk memenuhi kewajiban jangka pendek juga tinggi, begitu juga sebaliknya. Current ratio yang terlalu tinggi menunjukkan kelebihan aktiva lancar yang menganggur. Jadi hal tersebut tidak baik bagi profitabilitas perusahaan karena aktiva lancar menghasilkan return yang lebih rendah dibandingkan dengan aktiva tetap. Hasil penelitian ini sejalan dengan penelitian yang dilakukan oleh Rahmi (2014) namun berbeda dengan hasil penelitian yang dilakukan oleh Tommy, Christiano, dan Saerang (2014). Namun, penelitian yang dilakukan oleh Eng (2013) menyatakan bahwa risiko likuiditas memiliki pengaruh yang negatif namun signifikan terhadap ROA.

\section{Pengaruh Risiko Kredit terhadap Profitabilitas}

Berdasarkan hasil pengujian hipotesis kelima $\left(\mathrm{H}_{5}\right)$ ditunjukkan bahwa secara parsial risiko kredit berpengaruh negatif, tetapi tidak signifikan terhadap profitabilitas. Hal ini dapat dilihat dari nilai probabilitas risiko kredit $\left(\mathrm{X}_{5}\right)$ lebih besar daripada nilai kritis atau nilai standar 5\%, yaitu sebesar 0,0808 dengan nilai coefficient negatif, yaitu sebesar -0,165080. Dalam penelitian ini risiko kredit dihitung dengan DER (debt to equity ratio), sehingga dapat 
disimpulkan bahwa jika DER semakin tinggi maka profitabilitas akan semakin menurun, begitu juga sebaliknya.

Hal ini dapat disebabkan karena semakin rendah DER akan semakin baik kemampuan perusahaan dalam membayar kewajiban jangka panjangnya, sebaliknya semakin tinggi DER menunjukkan total hutang semakin besar dibanding dengan total modal sendiri, sehingga berdampak semakin besar beban perusahaan terhadap pihak luar (kreditur). Meningkatnya beban terhadap kreditur menunjukkan sumber modal perusahaan sangat tergantung dengan pihak luar. Selain itu, besarnya beban hutang yang ditanggung perusahaan dapat mengurangi jumlah laba yang diterima perusahaan (Trisnandari, 2015).

Hasil penelitian ini sejalan dengan penelitian yang dilakukan oleh Tommy, Christiano, dan Saerang (2014) namun berbeda dengan hasil penelitian yang dilakukan oleh Rahmi (2014), Eng (2013), dan Putri (2013) yang menyatakan bahwa risiko likuiditas berpengaruh negatif dan signifikan terhadap profitabilitas.

\section{Pengaruh Risiko Operasional terhadap Profitabilitas}

Berdasarkan hasil pengujian hipotesis keenam $\left(\mathrm{H}_{6}\right)$ ditunjukkan bahwa secara parsial risiko operasional berpengaruh negatif, tetapi tidak signifikan terhadap profitabilitas. Hal ini dapat dilihat dari nilai probabilitas risiko operasional $\left(\mathrm{X}_{6}\right)$ lebih besar daripada nilai kritis atau nilai standar 5\%, yaitu sebesar 0,2694 dengan nilai coefficient negatif, yaitu sebesar 0,441202. Dalam penelitian ini risiko operasional dihitung menggunakan Inventory Turn Over berarti makin sering barang dijual dan tentu saja makin menambah pendapatan perusahaan dan makin menambah keuntungan perusahaan. Akan tetapi, dalam kedua perusahaan minuman beralkohol yang diteliti didapatkan hasil bahwa, risiko operasional berpengaruh negatif dan tidak signifikan terhadap profitabilitas.

Berkurangnya distributor yang disebabkan oleh Permendag No. 6 tahun 2015, menyebabkan kedua perusahaan mendapatkan pengembalian barang dari berbagai distributor dan harus mengurangi shift kerja bahkan karyawan kontrak yang ada di perusahaan minuman beralkohol, sehingga persediaan barang jadi lebih sedikit dari biasanya. Dalam penelitian yang dilakukan oleh Djuhara dan Januariska (2014),Sistem Informasi Akuntansi Persediaan Barang (Perangkat Keras (hardware), Perangkat Lunak (software), Manusia (brainware), prosedur dan database dapat dikatakan berpengaruh terhadap pengendalian Intern Persediaan Barang. Mendapatkan pengembalian barang dari distributor membuat barang persediaan menumpuk, sehingga pendapatan perusahaan akan berkurang. Hasil penelitian ini sejalan dengan hasil penelitian yang dilakukan oleh Tommy, Christiano, dan Saerang (2014) serta Wibowo dan Syaichu (2013) namun berbeda dengan hasil penelitian yang dilakukan oleh Eng (2013).

\section{Simpulan dan Saran}

Simpulan. Berdasarkan hasil penelitian yang telah dilakukan, maka dapat ditarik kesimpulan dari beberapa hipotesis yang telah diajukan, diantaranya:

1. Risiko tingkat suku bunga secara parsial berpengaruh positif, tetapi tidak signifikan terhadap profitabilitas di perusahaan minuman beralkohol yang memproduksi minuman beralkohol golongan A dan tercatat di BEI periode 2013-2017.

2. Risiko inflasi secara parsial berpengaruh negatif, tetapi tidak signifikan terhadap profitabilitas di perusahaan minuman beralkohol yang memproduksi minuman beralkohol golongan A dan tercatat di BEI periode 2013-2017.

3. Risiko nilai tukar valuta asing secara parsial berpengaruh negatif signifikan terhadap profitabilitas di perusahaan minuman beralkohol yang memproduksi minuman beralkohol golongan A dan tercatat di BEI periode 2013-2017. 
4. Risiko likuiditas secara parsial berpengaruh negatif, tetapi tidak signifikan terhadap profitabilitas di perusahaan minuman beralkohol yang memproduksi minuman beralkohol golongan A dan tercatat di BEI periode 2013-2017.

5. Risiko kredit secara parsial berpengaruh negatif, tetapi tidak signifikan terhadap profitabilitas di perusahaan minuman beralkohol yang memproduksi minuman beralkohol golongan A dan tercatat di BEI periode 2013-2017.

6. Risiko operasional secara parsial berpengaruh negatif, tetapi tidak signifikan terhadap profitabilitas di perusahaan minuman beralkohol yang memproduksi minuman beralkohol golongan A dan tercatat di BEI periode 2013-2017.

7. Risiko sistematis dan risiko tidak sistematis secara simultan tidak memiliki pengaruh terhadap profitabilitas di perusahaan minuman beralkohol yang memproduksi minuman beralkohol golongan A dan tercatat di BEI periode 2013-2017.

Saran. Bagi akademik, disarankan untuk melanjutkan kembali penelitian ini dengan menambahkan faktor lain yang mempengaruhi profitabilitas sebesar 22,7209\% tersebut yang belum dapat dijelaskan dalam penelitian ini. Bagi perusahaan, disarankan untuk memperhatikan isu-isu peraturan pemerintah yang akan dikeluarkan, khususnya peraturan pemerintah yang merugikan bagi perusahaan. Bagi penelitian mendatang, disarankan untuk menambah variabel yang berkaitan dengan risiko sistematis dan risiko tidak sistematis pada perusahaan yang sejenis yaitu perusahaan minuman beralkohol, sehingga diharapkan mampu memberikan hasil yang akurat dan mampu melengkapi penelitian ini.

\section{DAFTAR PUSTAKA}

Ansofino, Jolianis, Yolamalinda, \& Arfilindo, H. (2016). Buku Ajar Ekonometrika. Yogyakarta: Deepublish.

Anwari, I. R. (2015). Minuman Keras Sebagai Necessary Evil di Surabaya 1900-1942. Mozaik Humaniora, XV, 205-206.

Asep Saepul Hamdi, E. B. (2014). Metode Penelitian Kuantitatif Aplikasi dalam Pendidikan. Yogyakarta: Deepublish.

Eng, T. S. (2013). Pengaruh NIM, BOPO, LDR, NPL \& CAR Terhadap ROA Bank Internasional Dan Bank Nasional Go Public Periode 2007 - 2011. Jurnal Dinamika Manajemen.

Kasmiarno, K. S. (2017). Analisis Pengaruh Indikator Ekonomi dan Kinerja Perbankan Syariah terhadap Penyerapan Tenaga Kerja Pada Perbankan Syariah di Indonesia Tahun 2008-2014. Jurnal Ekonomi Syariah Teori dan Terapan, 19.

Kurniawan, R., \& Yuniarto, B. (2016). Analisis Regresi: Dasar dan Penerapannya Dengan $R$. Jakarta: Kencana.

Mansyur, N. (2018). Pengaruh Risiko Pasar Terhadap Profitabilitas Perusahaan Sub Sektor Bank Pada Bursa Efek Indonesia. Jurnal Maksipreneur, 107-116.

Muslim, H Al-Kattani, A., \& Supraha, W. (2014). Menumbuhkan Karakter Anak (Perspektif Ibn Abd Al-Barr Al-Andalusi). Yogyakarta: Deepublish.

Prahara, H. (2018, September 27). Cerah, Masa Depan Industri Makanan dan Minuman di Indonesia. (M. Gewati, Editor) Retrieved Desember 5, 2018, from Kompas.com: https://ekonomi.kompas.com/read/2018/09/27/150000226/cerah-masa-depan-industrimakanan-dan-minuman-di-indonesia.

Pramesti, G. (2015). Kupas Tuntas Data Penelitian dengan SPSS 22. Jakarta: Gramedia.

Putri, F. S. (2013). Pengaruh Risiko Kredit dan Tingkat Kecukupan Modal Terhadap Tingkat Profitabilitas pada Perusahaan Perbankan Yang Terdaftar di Bursa Efek Indonesia. Universitas Negri Padang. 
Rahmi, C. L. (2014). Pengaruh Risiko Kredit, Risiko Likuiditas dan Risiko Tingkat Bunga Terhadap Profitabilitas. Universitas Negeri Padang.

Rini, A. S. (2018, agustus 13). Ini Kontribusi Industri Minuman Beralkohol Terhadap Kas Negara. (M. Ihsan, Editor) Retrieved desember 5, 2018, from Bisnis Indonesia: http://industri.bisnis.com/read/20180813/257/827433/ini-kontribusi-industriminuman-beralkohol-terhadap-kas-negara

Tommy, P., Christiano, M., \& Saerang, I. (2014). Analisis terhadap Rasio-Rasio Keuangan Untuk Mengukur Profitabilitas pada Bank-Bank Swasta yang Go Public di Bursa Efek Indonesia. EMBA, 817-830.

Wibowo, E. S., \& Syaichu, M. (2013). Analisis Pengaruh Suku Bunga, Inflasi, Car, Bopo, Npf terhadap Profitabilitas Bank Syariah . Diponegoro Journal of Management, 1-10.

Wijayanto, D. (2012). Pengantar Manajemen. Jakarta: PT Gramedia Pustaka Utama.

Yanti, D. F. (2015). Pengaruh Konservatisme Akuntansi, Risiko Sistematis, dan Ketepatwaktuan Informasi Terhadap Keresponan Laba pada Perusahaan Manufaktur yang Terdaftar di BEI Tahun 2009-2013. Universitas Negeri Padang.

Yasmin, P. A. (2018, April 23). Menperin: Industri Makanan dan Minuman Tumbuh 9,23\%. Retrieved desember 5, 2018, from Detik Finance: https://finance.detik.com/industri/d3985814/menperin-industri-makanan-dan-minuman-tumbuh-923.

Yudowati, S. P., Khairunnisa, \& Jati, N. A. (2017). Pengaruh Risiko Sistematik, Persistensi Laba, dan Ukuran Perusahaan Terhadap Koefisien Respon Laba (Studi pada Perusahaan yang Terdaftar di Indeks Kompas100 Periode 2011-2015). e-Proceeding of Management, 2776. 